UDC 69622.06

\title{
INCREASE IN FLUID EXTRACTION, WHICH IS AT THE FINAL STAGE OF DEVELOPMENT DUE TO THE IMPROVEMENT OF EQUIPMENT INTENSIFICATION
}

\author{
Rubel Victoria $^{1^{*}}$, Petruniak Marina ${ }^{2}$ \\ ${ }^{1}$ Poltava National Technical Yuri Kondratyuk University https://orcid.org/0000-0002-6053-9337 \\ ${ }^{2}$ Poltava National Technical Yuri Kondratyuk University https://orcid.org/0000-0002-8923-0640 \\ *Corresponding author E-mail: veca.rubel@gmail.com
}

It has been established that the fluid reserves, which are at the final stage of development, are difficult to extractable and watered. The methods of intensification are analyzed and it is established that it will be rational in this case to pump carbon dioxide into the reservoir. Its influence on a bundle of oil and water is determined. The results of the statistical processing of the change of the debit before and after injection of carbon dioxide, the influence of the volume of gas injected into the well from the seperate permeability of the reservoir, as well as the expected rate of wellbore after injection, are presented.

Keywords: buffer tanks for carbon dioxide, carbon dioxide, fluid, gas well, injection wells, productive layer, pump station, viscous oil sand, water content.

\section{ЗБІЛЬШЕННЯ ВИДОБУТКУ ФЛЮЇДУ, ЩО ЗНАХОДИТЬСЯ НА ЗАВЕРШАЛЬНІЙ СТАДІЇ РОЗРОБКИ, ЗА РАХУНОК УДОСКОНАЛЕННЯ ОБЛАДНАННЯ ІНТЕНСИФІКАЦІЇ}

\author{
Рубель В.П. ${ }^{*}$, Петруняк М.В. ${ }^{2}$ \\ 1,2 Полтавський національний технічний університет імені Юрія Кондратюка \\ *Адреса для листування E-mail: veca.rubel@gmail.com
}

\begin{abstract}
Установлено, що запаси флюїду родовища, яке знаходяться на завершальній стадії розробки, є важко видобувними й обводненими. Проаналізовано методи інтенсифікації і з'ясовано, що раціонально в такому випадку буде закачати в пласт вуглекислий газ. Визначено його вплив на в'язку нафту та на воду. Наведено результати статистичної обробки зміни дебіту до і після ін'єкції діоксиду карбону, впливу об'єму газу, що закачується у свердловину, від середньої проникності пласта, а також від очікуваного дебіту свердловини після проведення ін'єкції. Проаналізовано, що розробка газоконденсатних родовищ без підтримки пластового тиску (так званий «режим виснаження») призводить до втрат, часто значних, вуглеводневого конденсату. Для зменшення пластових втрат конденсату використовуються різні способи впливу на пласт, що передбачають нагнітання газів або води зазвичай при початкових пластових тисках. Використання цих методів вимагає великих інвестицій, що не завжди економічно виправдано. Нова технологія заснована на ефектах витіснення пластового жирного газу сухим, випаровування рідких ретроградних вуглеводнів, підтримки пластового і забійного тисків, блокування активної підошовної та законтурної води. Технологія забезпечує збереження фонду діючих свердловин, збільшення їх продуктивності та дебітів, підвищення вуглеводовіддачі пласта, підтримання сировинної бази газопереробного заводу, продовження періоду активного функціонування всієї створеної промислово-заводської інфраструктури. Для реалізації технології та досягнення ії проектної ефективності необхідно створити і впровадити нову надійну систему контролю за розробкою. Ця система повинна враховувати геолого-технологічні особливості об'єкта видобутку вуглеводнів і технології його розробки, маючи на увазі геологічну будову колектора, ефективні газонасичені товщини, термобаричні умови та ін. Вона має забезпечувати безперервний контроль інтервалів приймальності при закачуванні газу та інтервалів дренування при відборі вуглеводневої суміші, оперативне визначення компонентного складу продукції на основі застосування високоточної геофізичної та хроматографічної апаратури.
\end{abstract}

Ключові слова: буферні ємності для вуглекислого газу, вуглекислий газ, рідина, газові свердловини, нагнітальні свердловини, продуктивний пласт, насосна станція, в'язкість, пісок, вміст води. 


\section{Introduction}

The industrial problem of the oil industry is due to the fact that, due to the more intensive development of easily recovered oil fields, the share of hard - to - recovered reserves is constantly increasing, requiring the application of new methods of increasing oil production.

One of such complex methods is the injection of $\mathrm{CO}_{2}$ into the formation. The physical essence of the method is the good solubility of $\mathrm{CO}_{2}$ in formation fluids, which provides a volume expansion of oil in $1.5-1.7$ times, the ability to mix it with oil, reducing the viscosity of oil (from tens percent to several times) and, as a consequence, an increase in the crowding rate.

However, the application of this gas, as well as any other low - viscosity agent, is accompanied by a decrease in the coverage factor.

\section{Review of the research sources and publications}

Gas condensate deposits in their initial state are characterized by high reservoir pressures, usually reaching several tens of MPa. There are deposits with relatively low $(8-10 \mathrm{MPa})$ and very high (up to $150-180 \mathrm{MPa}$ ) initial reservoir pressures. The main reserves of hydrocarbons in deposits of gas - condensate type are confined to objects with initial reservoir pressures of $30-$ $60 \mathrm{MPa}$. In the domestic gas industry, the development of gas condensate deposits was carried out until recently in the mode of using only the natural energy of the reservoir. Such a mode ("exhaustion") requires for its implementation of the minimum capital investment and relatively moderate current material and financial costs. In contrast to the development of a purely gas reservoir, in this case it is necessary to deal with the product, the composition of which is constantly changing. This is due to the phenomena of retrograde condensation of the formation hydrocarbon mixture, which occur when the formation pressure is reduced. The high molecular weight hydrocarbon components of the mixture, after lowering the pressure in the reservoirs below the pressure of the condensation start, are transferred to the liquid phase, which remains immobile practically throughout the development of the deposit due to low phase saturation (no more than $12-15 \%$ ), much lower threshold of hydrodynamic mobility (about $40-50 \%$ ).

GS Stepanova and VN Shustef studied in detail the peculiarities of the process of differential condensation of the reservoir mixture, performing simultaneously for comparison of calculations by contact condensation. According to these researchers, the marginal pressure, below which the calculated composition of the gas phase for differential and contact processes is not the same, is approximately $20 \mathrm{MPa}[4,10,12]$.

\section{Problem statement}

To create and implement a scientifically - based monitoring system for the development of a gas - condensate deposit in conditions of low reservoir pressure with the effect on the reservoir by gas injection, which includes methods and means of control over the implementation of technology, methods for their forecasting.

\section{Basic material and results}

The injection of $\mathrm{CO}_{2}$ into the reservoir is one of the most effective ways to increase oil recovery. Dioxide of carbon, as well as hydrocarbon solvents, provides a very high percentage of extraction and deprived of their basic disadvantages - the price of the juice.

Carbon dioxide or carbon dioxide forms a liquid phase at temperatures below $310{ }^{\circ} \mathrm{C}$. At a temperature above $31{ }^{\circ} \mathrm{C}$, carbon dioxide is in a gaseous state, with a pressure of less than 7.2 $\mathrm{MPa}$ - from the liquid passes into a vaporous.

The principle of application [4] $\mathrm{CO}_{2}$ is based on the dependence of the viscosity of fluids in reservoir conditions on the amount of $\mathrm{CO}_{2}$ dissolved in them. For example, the dissolution of $\mathrm{CO}_{2}$ in oil reduces its viscosity within $10-50 \%$. At the same time, the volume ratio of oil with dissolved gas increases to $50 \%$.An increase in the volume of oil contributes to the growth of the volume of pores occupied by oil, creates favorable conditions for its movement. Reducing the viscosity of the oil leads to an increase in its mobility. In this regard, in order to achieve a given coefficient of oil consumption, a smaller amount of displacing agent is spent.

Due to the solubility of $\mathrm{CO}_{2}$ in reservoir water, the initial viscosity of water is noticeably increased, as a result of the ratio of the movement of oil and water increases. Dioxide of carbon in the system also leads to a decrease in the surface tension at the boundary of oil water.

Efficiency of displacement of oil by carbon dioxide is determined both by increasing the coefficient of coverage by the effect and displacement. The increase in the coverage factor by area and volume is due to improved capillary absorption and equalization of the mobility of water and oil.

The ability of carbon dioxide to be readily dissolved in oil and water is a key property that determines the high efficiency of oil displacement with the use of carbon dioxide.

This property also contributes to the separation and washing of the oil film from the top of the rock, increases the wettability of the porous medium with water and thus contributes to capillary water collection in a porous medium saturated with oil, resulting in an increase in the amount of oil displaced. Depending on the composition of oil, pressure, temperature, the solubility of $\mathrm{CO}_{2}$ in it may be either limited, or close to unlimited. The solubility of carbon dioxide in real oil can reach hundreds of volumes of $\mathrm{CO}_{2}$ per one volume of oil. So, in other equal conditions, carbon dioxide is better soluble in petroleum with a high content of hydrocarbons in the C3 - C7 series. The high content of resins and asphaltenes in oil, on the contrary, greatly complicates its dissolution. For this reason, unlimited solubility of carbon dioxide in oil is practically impossible. Dioxide of carbon, depending on the thermodynamic conditions 
(pressure, temperature) can be in solid, liquid and gaseous state (Fig. 1).

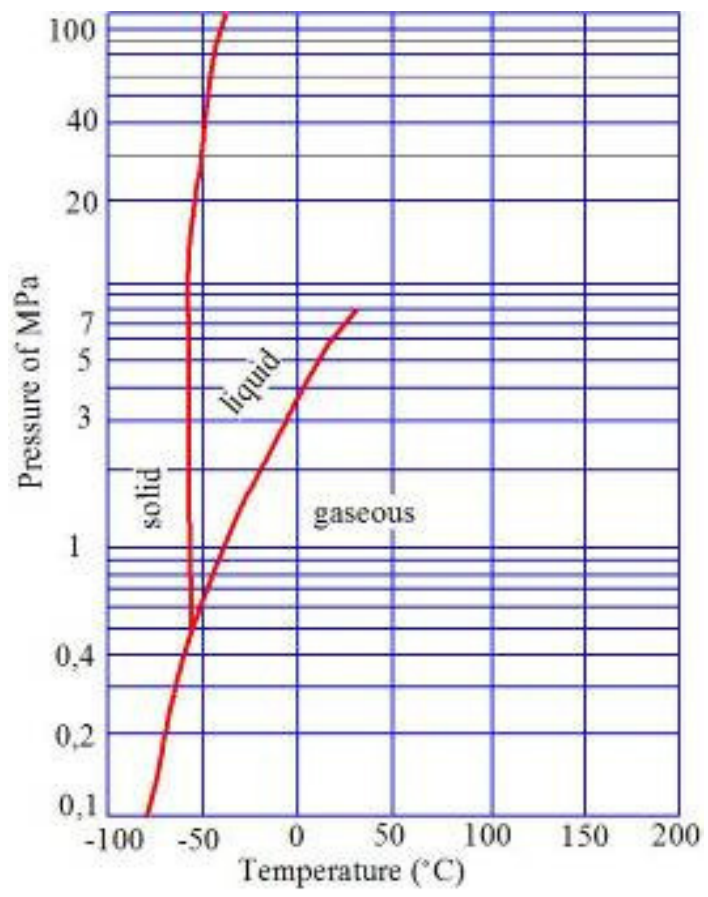

Figure 1 - Carbon dioxide phase diagram

In the chart below, we can judge what kind of oil displacement using carbon dioxide will occur at specific reservoir temperatures and pressures. So, if [5] the formation temperature is $<319^{\circ} \mathrm{C}$. and pressure $>7.5 \mathrm{MPa}$, then the oil will be replaced by liquid carbon dioxide. If the formation temperature is $>31^{\circ} \mathrm{C}$, the most likely is the displacement of oil by carbon dioxide.

The gaseous carbon dioxide is colorless, has a slightly sour smell and taste. The molecular weight of the compound is 44.010 . The density of $\mathrm{CO}_{2}$ at normal pressure and temperature $00 \mathrm{C}$ is $1.98 \mathrm{~kg} / \mathrm{m}^{3}$.

With increasing temperature under constant pressure and oil composition, the efficiency of $\mathrm{CO}_{2}$ in it decreases. With constant oil composition and temperature increase of pressure causes increase of solubility of carbon dioxide. Dioxide of carbon dissolves sufficiently well in water. However, this process is limited in nature. It is influenced by pressure, temperature and degree of mineralization. So, with increasing pressure at constant mineralization and temperature, the solubility of carbon dioxide in water rises. With constant mineralization of water and pressure with increasing temperature the process is ambiguous. When [4] constant pressure and temperature with an increase in mineralization, the solubility of $\mathrm{CO}_{2}$ in water decreases. Depending on the specific conditions, the solubility of carbon dioxide in water can reach $20 \%$.

The aqueous solution of carbon dioxide reacts with carbonates in kind, dissolves them, while increasing the permeability of the collector and absorbing the ability of the injection wells. When dissolved in carbon dioxide in oil and water, the viscosity of the latter varies.
So, with the increase in the content of dissolved $\mathrm{CO}_{2}$ depending on the composition of oil, pressure, the degree of pressure and temperature, there is a decrease in the viscosity in $2-15$ times compared with the initial at zero content of carbon dioxide, while for more viscous oil in much higher degree than for less viscous.

With increasing pressure at constant values of the initial composition of oil and temperature, its viscosity with $\mathrm{CO}_{2}$ dissolved in it takes ever lesser significance. This is due to the increase in the content of dissolved carbon dioxide in oil.

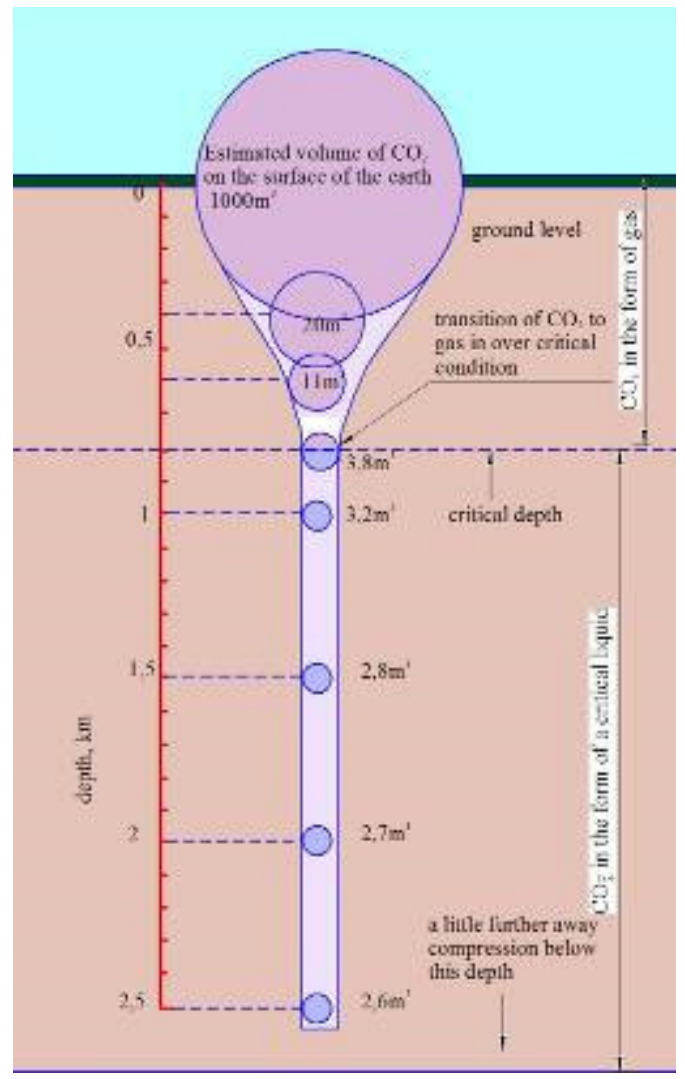

Figure 2 - The scheme of transition of carbon dioxide into a liquid state

With the constant composition of oil and pressure with increasing temperature, the viscose oil when dissolved in it, $\mathrm{CO}_{2}$ is reduced to a lesser extent, as the solubility of carbon dioxide also decreases. Knowledge of the mechanism of reducing the viscosity of oil when dissolved in it, $\mathrm{CO}_{2}$ is necessary in the prediction of technological indicators of processes of displacement of oil using carbon dioxide.

At constant saturation pressure with increasing concentration of carbon dioxide the density of oil increases. Increasing the pressure above saturation pressure also contributes to increasing its density. As the temperature rises, it decreases. The pressure, the composition of oil, the ratio of volumes of gas and oil and temperature affect the change in the density of oil with dissolved $\mathrm{CO}_{2}$ to the same extent as these factors affect the very solubility of carbon dioxide in oil. When carbon dioxide is 
dissolved, carbon dioxide is formed in water, which, interacting with carbonate rocks - dolomite, sandstone with carbon - tinny cement, leads to an increase in porosity, permeability, degree of heterogeneity of these rocks.

The mechanisms discussed above for reducing the viscosity and increasing the volume of oil when dissolved in it, carbon dioxide leads to an increase in the mobile - state of the oil phase, which facilitates the displacement of oil. In addition, there is an increase in phase permeabilities for oil and water when they are in contact with $\mathrm{CO}_{2}$.

Thus, carbon dioxide [9] when interacting with oil, water and the rhizome phase causes a change in the physical and chemical properties of the latter.
Carbon dioxide or carbon dioxide forms a liquid phase at temperatures below $31{ }^{\circ} \mathrm{C}$. At a temperature above $31^{\circ} \mathrm{C}$, carbon dioxide is in a gaseous state, with a pressure of less than $7.2 \mathrm{MPa}$ - from the liquid passes into a vaporous.

The technological scheme of injection of $\mathrm{CO}_{2}$ is based on the existing general scheme of industrial arrangement of the deposit and, in particular, on the use of objects of the existing flood system. At the same time it is possible to supply $\mathrm{CO}_{2}$ to well, using the injection pipelines of the existing production system, to build new pipelines or to deliver tanks.

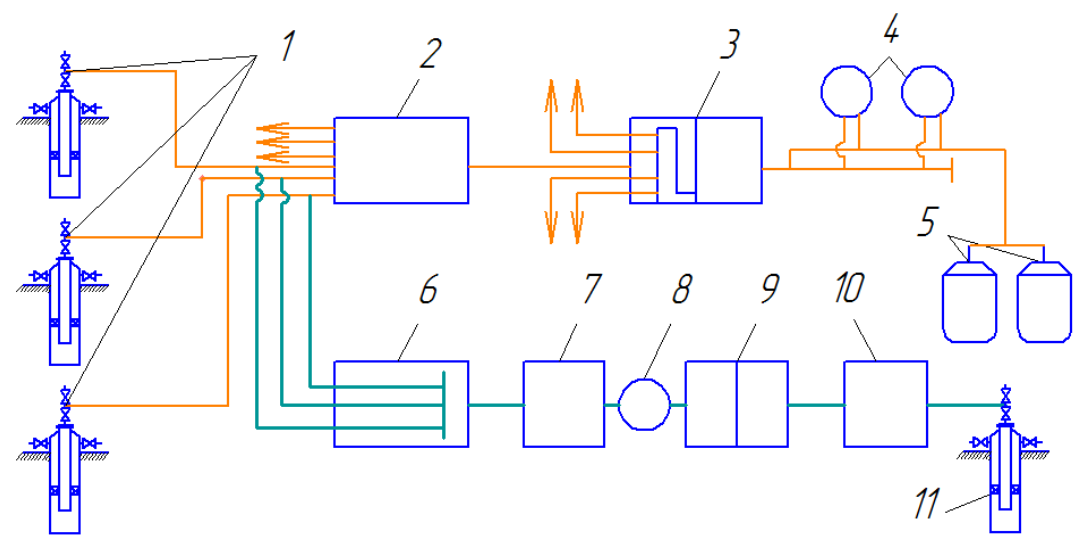

Figure 3 - Technological scheme of injection of $\mathrm{CO}_{2}$ :

1 - injection wells; 2 - point of distribution $\mathrm{CO}_{2} ; 3$ - pumping station; 4 - buffer tanks for $\mathrm{CO}_{2}$;

$5-\mathrm{CO}_{2}$ tanks; 6 - pressure head of the flood system; 7 - block bush pumping station; 8 - buffer tanks;

9 - the main pumping station and water treatment station; 10 - station of the first lifting; 11 - water well

The $\mathrm{CO}_{2}$ is pumped into the reservoir on the column of the pump - compressor pipes. For maintenance of the operating column from corrosion and high injection pressures, created when the $\mathrm{CO}_{2}$ is injected into the formation, into the injection wells, injecting the packer devices. Wells are equipped with a standard fitting with the necessary devices to control the process of pumping $\mathrm{CO}_{2}$ into the formation.

To pump $\mathrm{CO}_{2}$, special acid - proof pumps with remote control and automatic protection are used. For a continuous supply of $\mathrm{CO}_{2}$ in the pumping station, reserve pumps are provided. All technological pipelines of a pumping station should be calculated on a pressure with a 1: 4 stock ratio.

The hydrocarbonic acid of $\mathrm{H}_{2} \mathrm{CO}_{3}$ formed during the dissolution of $\mathrm{CO}_{2}$ in water dissolves cement in the formation of the formation and thus increases the permeability. Dioxide of carbon in water contributes to the breakdown and "laundering" of film oil that covers the grain of the breed and reduces the possibility of breaking the water film.

At reservoir pressure above [8], the pressure of complete mixing of carbon monoxide from carbon monoxide will suppress oil as an ordinary solvent (mixing displacement).

In a layer three zones are formed:
1) the zone of primitive reservoir oil;

2) transition zone;

3) a zone of clean $\mathrm{CO}_{2}$.

If $\mathrm{CO}_{2}$ is injected into a flooded deposit, then a $\mathrm{CO}_{2}$ shaft is formed in front of the $\mathrm{CO}_{2}$ zone, which displaces the formation water.

Dioxide of carbon has oil - retaining properties, due to its abilities:

1) readily dissolve in oil and in sewage water, and vice versa, dissolve in itself oil and water;

2) reduce the viscosity of oil, and increase the viscosity of water when dissolved in them, reducing the mobility of water relative to oil;

3 ) to increase the volume of oil when dissolved in it $\mathrm{CO}_{2}$ and to increase the efficiency of displacement of oil [10];

4) to reduce the interfacial tension on the edge of oil and water, to improve the moisture of the rock with water when dissolved in oil and water and to ensure the transfer of oil from the film state to the drip;

5) increase the permeability of individual types of collectors as a result of chemical interaction of coal and rock skeletons;

With the displacement of $\mathrm{CO}_{2}$ oil, depending on the specific conditions, different schemes may apply (Table 1). 
Displacement with mixing. The displacement scheme is carried out by feeding both gaseous and liquid carbon dioxide into the formation. Prerequisite is $P_{p l}>R_{m}$ (mixing), the pressure at which the total mutual dissolution of the displacing agent and the extruded medium occurs. The mixing pressure depends on the temperature and composition of the formation oil, which is generally characterized by the molecular weight. The displacing agent zone in which carbon dioxide is located, as a rule, in a gaseous $\left(T_{p 1} \geq T_{c r}\right)$, or in a liquid state $\left(T_{p 1} \leq T_{c r} ; P_{p 1} \geq P_{s}\right)$. When $P_{p 1} \geq P_{s}$, the zone of complete mutual solubility is absent and it turns out that displacement occurs without mixing [7].

Oil displacement with gaseous carbon dioxide. At subcritical temperatures in shallow oil horizons and at limited pumping rates provided $-P_{p 1}$ (reservoir pressure $)<P_{s}$ (condensation pressure $\mathrm{CO}_{2}$ ). At supercritical temperature $\left(T_{p 1} \leq T_{c r}\right.$, where $T_{p 1}$ is the formation temperature, $T=31.04{ }^{\circ} \mathrm{C}$ is the critical temperature of $\mathrm{CO}_{2}$ ), the displacement process is not thermodynamically limited and proceeds at any pressure values in the formation. Elimination of liquefied $\mathrm{CO}_{2}$. Realized with $T_{p 1}<T_{c r}, P_{p 1}>P_{s}$. Component and phase characteristics of this scheme: repressing agent - liquid $\mathrm{CO}_{2}$, displaced environment - liquid hydrocarbons and formation water.

The displacement is carbonated with water. Less [8] depends on pressure and temperature, with two - phase (liquid - liquid) filtration taking place, and $\mathrm{CO}_{2}$ is present in both phases, more in water and less in displaced oil - in the zone adjoining the boundary of the phase separation. Pressure with more pressure of the power of $\mathrm{CO}_{2}$ in water $-P_{\text {solute }}$.

Table 1 - Mechanism and schemes of influence

\begin{tabular}{|c|c|c|c|c|}
\hline \multirow{2}{*}{$\begin{array}{l}\text { Scheme of } \\
\text { influence }\end{array}$} & \multirow{2}{*}{$\begin{array}{l}\text { Mechanism of } \\
\text { displacement, } \\
\text { acting under } \\
\text { this scheme }\end{array}$} & \multicolumn{2}{|c|}{ Thermodynamic constraints } & \multirow{2}{*}{$\begin{array}{l}\text { Characteristics of the fluid: components, } \\
\text { phases }\end{array}$} \\
\hline & & $\begin{array}{l}\text { by tempera- } \\
\text { ture }\end{array}$ & by pressure & \\
\hline $\begin{array}{l}\text { Exhaust gas- } \\
\text { eous } \mathrm{CO}_{2}\end{array}$ & $\begin{array}{l}\text { Displacement } \\
\text { with mixing. } \\
\text { Change in vis- } \\
\text { cosity }\end{array}$ & $\begin{array}{l}T \leq T_{c r} \\
T \geq T_{c r}\end{array}$ & $P \leq P_{s}$ & $\begin{array}{l}\text { Gas phase: } \mathrm{CO} 2 . \\
\text { Liquid phase or gas - liquid mixture: hydro- } \\
\text { carbons (petroleum) }\end{array}$ \\
\hline $\begin{array}{l}\text { Exhaust gas- } \\
\text { eous } \mathrm{CO}_{2}\end{array}$ & $\begin{array}{l}\text { Displacement } \\
\text { with mixing }\end{array}$ & $T \geq T_{c r}$ & $P \leq P_{s}$ & Carbon dioxide, oil \\
\hline $\begin{array}{l}\text { Displacement } \\
\text { with mixing }\end{array}$ & $\begin{array}{l}\text { Displacement } \\
\text { with mixing. } \\
\text { Bulk effect }\end{array}$ & $\begin{array}{l}T \leq T_{c r} \\
T \geq T_{c r}\end{array}$ & $P \geq P_{m i x}$ & $\begin{array}{l}\text { 1. Liquid hydrocarbon phase. } \\
\text { 2. A gas - liquid zone: a mixture of explo- } \\
\text { sives and carbon dioxide. } \\
\text { 3. Zone of complete mutual solubility: gase- } \\
\text { ous mixture of hydrocarbons and } \mathrm{CO}_{2} \text { (with- } \\
\text { out boundaries of phases). } \\
\text { 4. Propagation zone: gaseous (predomi- } \\
\text { nantly) or liquid (sometimes) } \mathrm{CO}_{2} \text {. } \\
\text { 5. The zone of complete mutual solubility is } \\
\text { absent. }\end{array}$ \\
\hline $\begin{array}{l}\text { Displacement } \\
\text { with car- } \\
\text { bonated wa- } \\
\text { ter }\end{array}$ & $\begin{array}{l}\text { Change of vis- } \\
\text { cosity of inter- } \\
\text { phase tension }\end{array}$ & $\begin{array}{l}T \leq T_{c r} \\
T \geq T_{c r}\end{array}$ & $\begin{array}{l}P \leq P_{\text {mix }} \\
P \geq P_{s}\end{array}$ & $\begin{array}{l}\text { Oil phase: hydrocarbons and } \mathrm{CO}_{2} \text { (insignifi- } \\
\text { cant quantity). } \\
\text { Water phase: water and } \mathrm{CO}_{2} \text { (high content). } \\
\text { Gas phase: hydrocarbons and } \mathrm{CO}_{2} \text {. }\end{array}$ \\
\hline
\end{tabular}

An aqueous solution of carbon dioxide reacts with carbonate in - kind, dissolves them, while increasing permeability. We calculate how the well flow changes after the injection into the carbon dioxide layer and how the permeability changes with the following output data (Table 2).

The radius of the carbon dioxide penetration zone:

$$
\begin{aligned}
r_{w} & =0.5 D=0.73 \mathrm{~m} ; \\
R_{\mathrm{CO}_{2}} & =\sqrt{\left(\frac{V_{\mathrm{CO}_{2}}}{\pi \cdot h \cdot m}\right)+r_{w}{ }^{2}} .
\end{aligned}
$$

The permeability of the bottomhole zone of the reservoir after injection of $\mathrm{CO}_{2}$ is equal (according to industrial data): $c_{\kappa}=0.12-$ coefficient of carbonaceous rock;

$$
k_{p}=1.8 \cdot e^{\left(0.25 c_{k}\right)} \text {; }
$$

$k=2.15-$ growth rate of permeability;

$$
k_{b f z}=k_{p} \cdot k \text {. }
$$

Average (reduced) reservoir permeability after injection of carbon dioxide

$$
k_{m}=\frac{k \cdot k_{b f z} \cdot \log \left(\frac{R_{k}}{r_{w}}\right)}{k_{b f z} \cdot \log \left(\frac{R_{\mathrm{CO}_{2}}}{r_{w}}\right)+k \cdot \log \left(\frac{R_{k}}{r_{\mathrm{CO}_{2}}}\right)} .
$$


Expected effect after injection of carbon dioxide $\left(\mathrm{CO}_{2}\right)$

$$
E=k_{m} / k \text {. }
$$

Determine the expected well flow after loading $\mathrm{CO}_{2}$

$$
q_{2}=q_{1} F,
$$

where $q_{1}$ - the discharge of the well to the injection of carbon dioxide.

Determine the expected oil well after the injection of carbon dioxide, with known water content of the product.

$$
q_{2 \mathrm{n}}=q_{2}(1-n) .
$$

This calculation will be carried out 15 times. The obtained results will be analyzed using statistical analysis, and for this we will use the STATISTIKA 10 program.

Having statically processed the results got: - the dependence of the volume of $\mathrm{CO}_{2}$ injection from the average reservoir permeability after injection of $\mathrm{CO}_{2}$, where the correlation coefficient was $r=0.995$, and Fisher's criterion is equal $F=107.02$ at a critical point $F_{\text {critical }}=161.45$

$$
V_{\mathrm{CO}_{2}}=14.2+0.8594 k_{m}
$$

- the dependence of the volume of pumping of $\mathrm{CO}_{2}$ from the expected debit of the well after the injection of $\mathrm{CO}_{2}$, where the correlation coefficient $r=0.98$, and Fisher's criterion $F=42.56$ at a $F_{\text {critical }}=161.45$

$$
q_{2}=7.8928+1.0629 V_{\mathrm{CO}_{2}} ;
$$

- dependence of the well flow to the injection of carbon dioxide from the expected value of the well bore at the known watering of the products where the correlation coefficient $r=0.998$, and Fisher's criterion $F=37.824$ at a $F_{\text {critical }}=161.45$

$$
q_{2}=4.4664+0.9578 q_{1} ;
$$

- dependence of the well flow rate on the injection of dioxide from the expected well flow at the known watering of the products carbon where the correlation coefficient $r=0.999$, and Fisher's criterion $F=33.110$ at a $F_{\text {critical }}=161.45$

$$
q_{1}=0,5751+0.9934 q_{2} .
$$

Since $F_{p} \geq F_{\text {critical }}$, the obtained regression equation is assumed to be statistically significant. (The hypothesis of model adequacy was confirmed in all cases).

The results indicate that an important role in the injection of carbon dioxide is played by indicators such

\begin{tabular}{|c|c|c|c|c|c|c|c|c|c|}
\hline № & 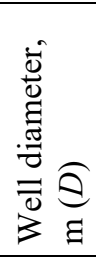 & 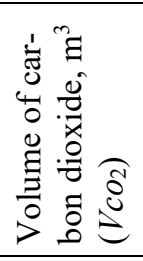 & 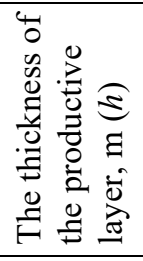 & 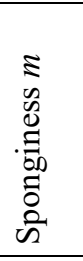 & 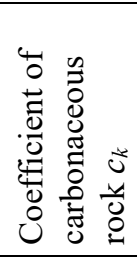 & 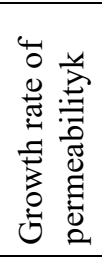 & 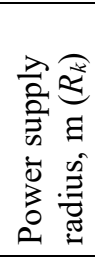 & 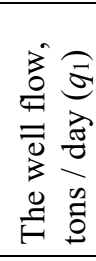 & 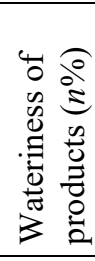 \\
\hline 1 & 0.245 & 12 & 11 & 0.12 & 5.11 & $5 E^{-14}$ & 850 & 4.56 & 55 \\
\hline 2 & 0.089 & 14 & 15 & 0.16 & 5.96 & $5 E^{-14}$ & 800 & 3.74 & 63 \\
\hline 3 & 0.095 & 17 & 17 & 0.16 & 7.24 & $5 E^{-14}$ & 750 & 2.23 & 78 \\
\hline 4 & 0.219 & 11 & 10 & 0.12 & 4.68 & $5 \mathrm{E}^{-14}$ & 700 & 3.74 & 63 \\
\hline 5 & 0.273 & 12 & 13 & 0.12 & 5.11 & $5 \mathrm{E}^{-14}$ & 650 & 3.32 & 65 \\
\hline 6 & 0.219 & 15 & 14 & 0.16 & 6.39 & $5 E^{-14}$ & 600 & 2.88 & 75 \\
\hline 7 & 0.245 & 18 & 18 & 0.22 & 7.66 & $5 \mathrm{E}^{-14}$ & 550 & 2.23 & 78 \\
\hline 8 & 0.273 & 18 & 20 & 0.22 & 7.66 & $5 \mathrm{E}^{-14}$ & 500 & 1.38 & 87 \\
\hline 9 & 0.299 & 12 & 12 & 0.14 & 5.11 & $5 \mathrm{E}^{-14}$ & 450 & 4.56 & 55 \\
\hline 10 & 0.325 & 15 & 16 & 0.16 & 6.39 & $5 \mathrm{E}^{-14}$ & 400 & 1.38 & 63 \\
\hline 11 & 0.351 & 15 & 15 & 0.16 & 6.39 & $5 \mathrm{E}^{-14}$ & 350 & 1.38 & 87 \\
\hline 12 & 0.377 & 11 & 10 & 0.12 & 4.68 & $5 \mathrm{E}^{-14}$ & 300 & 2.23 & 78 \\
\hline 13 & 0.426 & 17 & 17 & 0.22 & 7.24 & $5 \mathrm{E}^{-14}$ & 250 & 2.88 & 75 \\
\hline 14 & 0.457 & 15 & 15 & 0.16 & 6.39 & $5 E^{-14}$ & 200 & 1.98 & 80 \\
\hline 15 & 0.508 & 11 & 11 & 0.12 & 4.68 & $5 \mathrm{E}^{-14}$ & 250 & 2.51 & 76 \\
\hline
\end{tabular}
as reservoir permeability and water content of products. We have received that the rate will increase almost twice, if the production of wells will not be watered, and if the well products are significantly watered, then we will get equal oil extraction after the injection $\mathrm{CO}_{2}$.

Table 2 - Output data for the design of the process of injection of carbon dioxide into the formation 
Table 3 - Results of designing the process of carbon dioxide injection

\begin{tabular}{|c|c|c|c|c|c|c|c|c|}
\hline № & 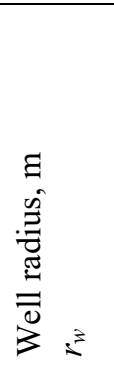 & 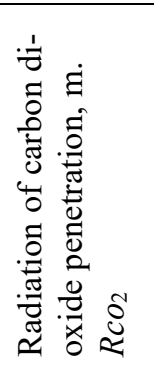 & 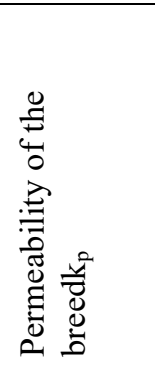 & 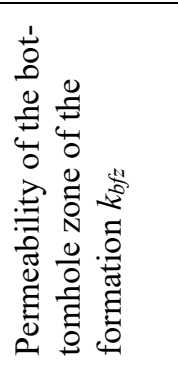 & 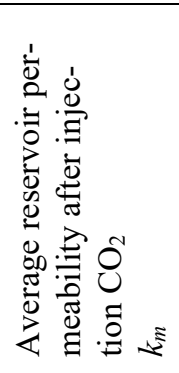 & 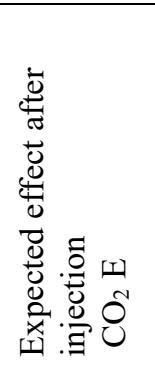 & 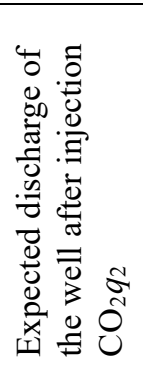 & 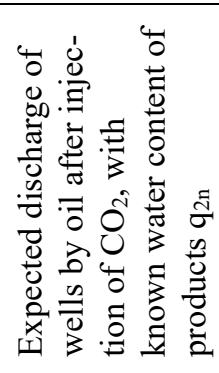 \\
\hline 1 & $0.122 \mathrm{~J}$ & 1.705931 & 6.456173 & $3.22809 \mathrm{E}^{-13}$ & $1.22989 \mathrm{E}^{-13}$ & 2.459781 & 11.2166 & 5.047471 \\
\hline 2 & 0.0445 & 1.363719 & 7.98777 & $3.99389 \mathrm{E}^{-13}$ & $1.16063 \mathrm{E}^{-13}$ & 2.321259 & 8.68151 & 3.212159 \\
\hline 3 & 0.0475 & 1.411631 & 10.99262 & $5.49631 \mathrm{E}^{-13}$ & $1.21978 \mathrm{E}^{-13}$ & 2.439561 & 5.440221 & 1.196849 \\
\hline 4 & 0.1095 & 1.712107 & 5.804301 & $2.90215 \mathrm{E}^{-13}$ & $1.15741 \mathrm{E}^{-13}$ & 2.314818 & 8.657418 & 3.203245 \\
\hline 5 & 0.1365 & 1.571118 & 6.456173 & $3.22809 \mathrm{E}^{-13}$ & $1.25403 \mathrm{E}^{-13}$ & 2.50807 & 8.326792 & 2.914377 \\
\hline 6 & 1095 & 1.464449 & 8.884864 & $4.44243 \mathrm{E}^{-13}$ & $1.31618 \mathrm{E}^{-13}$ & 2.632363 & 7.581206 & 1.895301 \\
\hline 7 & 0.1225 & 1.209381 & 12.22718 & $6.11359 \mathrm{E}^{-13}$ & $1.50695 \mathrm{E}^{-13}$ & 3.013897 & 6.720991 & 1.478618 \\
\hline 8 & 0.1365 & 1.149552 & 12.22718 & $6.11359 \mathrm{E}^{-13}$ & $1.56147 \mathrm{E}^{-13}$ & 3.122938 & 4.309655 & 0.560255 \\
\hline 9 & 0.1495 & 1.515634 & 6.456173 & $3.22809 \mathrm{E}^{-13}$ & $1.25224 \mathrm{E}^{-13}$ & 2.504482 & 11.42044 & 5.139198 \\
\hline 10 & 0.1625 & 1.375663 & 8.884864 & $4.44243 \mathrm{E}^{-13}$ & $1.40722 \mathrm{E}^{-13}$ & 2.814435 & 3.88392 & 1.43705 \\
\hline 11 & 0.1755 & 1.421705 & 8.88 & $4.44243 \mathrm{E}^{-13}$ & $1.40098 \mathrm{E}^{-13}$ & 2.801964 & 3.86671 & 0.502672 \\
\hline 12 & 0.1885 & 1.718969 & 5.804301 & $2.90215 \mathrm{E}^{-13}$ & $1.18921 \mathrm{E}^{-13}$ & 2.378412 & 5.303858 & 1.166849 \\
\hline 13 & 0.213 & 1.22187 & 10.99262 & $5.49631 \mathrm{E}^{-13}$ & $1.58409 \mathrm{E}^{-13}$ & 3.168187 & 9.12438 & 2.281095 \\
\hline 14 & 0.2285 & 1.429216 & 8.884864 & $4.44243 \mathrm{E}^{-13}$ & $1.41757 \mathrm{E}^{-13}$ & 2.83515 & 5.613597 & 1.122719 \\
\hline 15 & 0.254 & 1.64877 & 5.804301 & $2.90215 \mathrm{E}^{-13}$ & $1.25968 \mathrm{E}^{-13}$ & 2.519356 & 6.323583 & 1.51766 \\
\hline
\end{tabular}
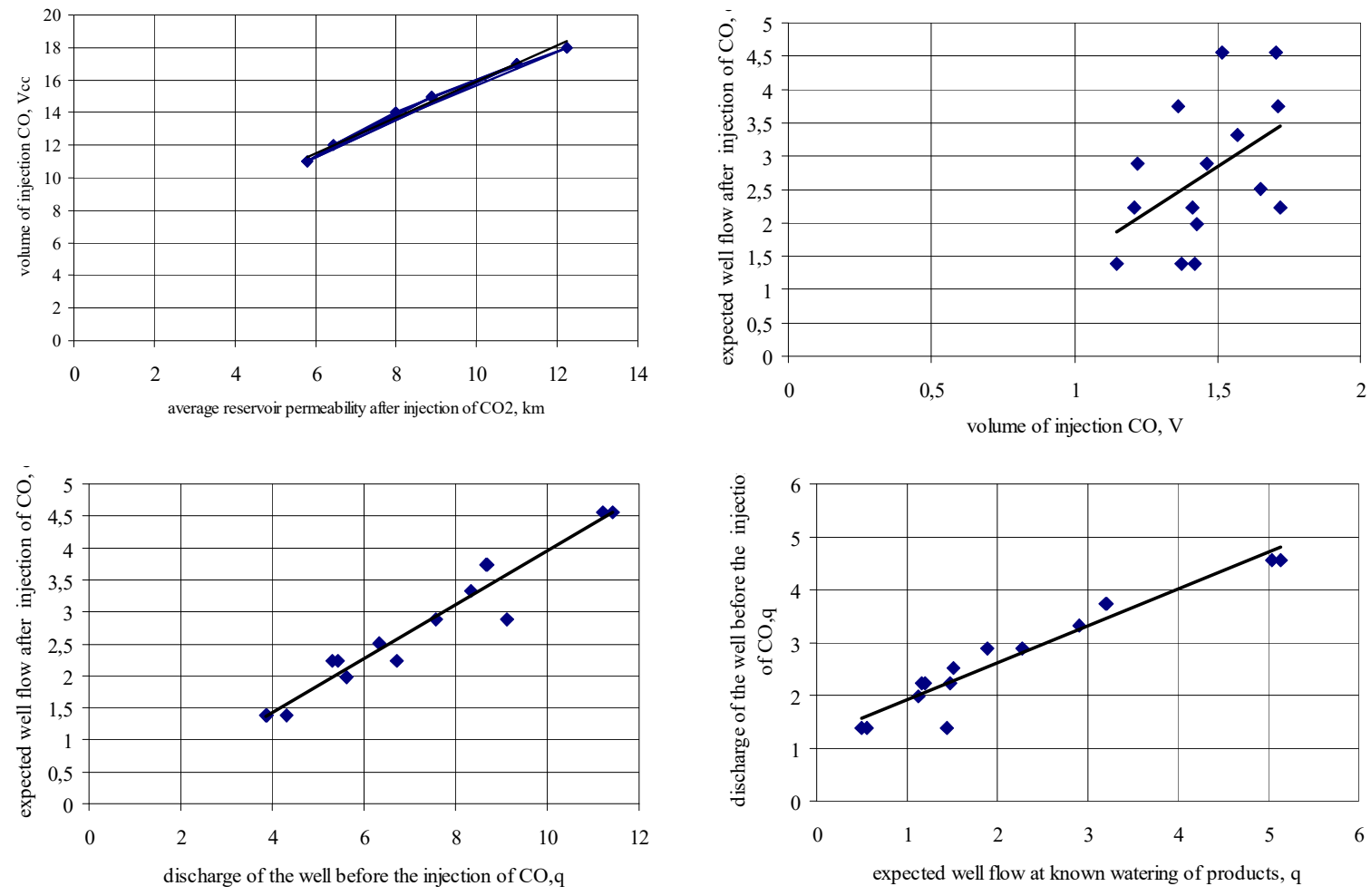

Figure 4 - Graphic dependences of the statistical processing results 


\section{Conclusions}

It is known that it is very difficult to extract residual oil reserves of especially viscous and saturated water, and when the carbon dioxide is pumped out, which dissolves well into the oil, increases its volume and reduces the viscosity, on the other hand, dissolves in water, increases its viscosity.
Thus, the distillation of carbon dioxide in oil and water leads to equalization of the mobility of oil and water, which creates opportunities for obtaining higher oil yields, both by increasing the displacement ratio and the coefficient of coverage of the oil deposit.

\section{References}

1. Антипин, Ю.В., Лысенков, А.В., Карпов, А.А., Тухтеев, Р.М., Ибраев, Р.А., Стенечкин, Ю.Н. (2007). Интенсификачия добычи нефти из карбонатных пластов (№7). Уфа. Нефтяное хозяйство.

2. Галлямов, И.М., Вахитов, Т.М., Шафикова, Е.А., Апкаримова, Г.И, Судаков, М.С., Самигуллин, И.Ф., (2008). К проблеме применяемости полимерных составов в условиях низких температур. Новое в геологии $u$ разработке нефтяных месторождений Башкортостана, 120, 221-225.

3. Гафаров, Ш.А., Шамаев, Г.А., Сафонов, Е.Н. (2005). Особенности фильтрации неньютоновских нефтей в карбонатных пористых средах. Нефтяное хозяйство, 11, 52-54.

4. Рубель, В.П. (2018). Оценка эффективности методов интенсификации на примере условий Бильского нефтегазоконденсатного месторождения. World Science, 6(34), 465-51.

https://doi.org/10.31435/rsglobal ws/12062018/5819

5. Рубель, В.П. (2018). Повышение ээффективности технологии интенсификации добычи газа на примере Коломацкого газоконденсатного месторождения: International Trends in Science and Technology, 1, 57-60.

6. Vynnykov, Yu., Manhura, A., Zimin, O. \& Matviienko, A. (2019). Use of thermal and magnetic devices for prevention of asphaltene, resin, and wax deposits on oil equipment surfaces. Mining of Mineral Deposits, 13(2), 34-40.

https://doi.org/10.33271/mining13.02.034

7. Chatterjee, S. \& Hadi, A. (2006). Regression analysis by example: Hoboken, NJ: Wiley.

8. Patsy, E. (2018). Advances In Unconventional Gas. Solutions to meet growing gas demand worldwide. A publication of Hart Energy Publishing. Retrieved from: www.hartenergy.com

9. Cambell, B.L. \& Chmilowski, W. (2005). Effective Stimultion of lowp ermeability gas in Western Canada. Journal Can. Petrol. Technol, 14(2). 17-22.

10. Mykhailovska, O., Rubel, V., Oleksiienko, O. \& Petruniak, M. (2018). Method of evaluation of stress - strain state rock around well. International Journal of Engineering \& Technology, 7(4.8). 312-318.

https://doi.org/10.14419/ijet.v7i4.8.27262

11. Ko, S.C.M., Stanton, P.M. \& Stephenson, D.J. (1985). Tertiary recovery potential of $\mathrm{CO} 2$ flooding in Joffre Viking Pool Alberta. Journal of Canadian Petroleum, 1. 36-43.

12. Heddle, G., Herzog, H. \& Klett, M. (2003). The economics of $\mathrm{CO}_{2}$ storage. Eds Massachusetts Institute of Technology, 111.
1. Antipin, Yu.V., Lysenkov, A.B., Karpov, A.A., Tukhteev, P.M., Ibraev, P.A., Stenechkin, Yu.N. (2007). Intensification of oil production from carbonate formations (No. 7). Ufa Oil industry.

2. Gallyamov, I.M., Vakhitov, T.M., Shafikova, E.A., Apkarimova, G.I., Sudakov, M.S., Samigullin, I.F., (2008). To the problem of applicability of polymer compositions at low temperatures. New in geology and development of oil fields of Bashkortostan, 120, 221-225.

3. Gafarov, Sh.A., Shamaev, G.A., Safonov, E.H. (2005). Features of the filtration of non - Newtonian oils in carbonate porous media. Oil industry, 11, 52-54.

4. Rubel, V.P. (2018). Evaluation of the effectiveness of intensification methods on the example of the conditions of the Bilskoye oil and gas condensate field. World Science, 6(34), 46-51.

https://doi.org/10.31435/rsglobal_ws/12062018/5819

5. Rubel, V.P. (2018). Improving the efficiency of gas production intensification technology as exemplified by the Kolomatsk gas condensate field: International Trends in Science and Technology, 1, 57-60.

6. Vynnykov, Yu., Manhura, A., Zimin, O. \& Matviienko, A. (2019). Use of thermal and magnetic devices for prevention of asphaltene, resin, and wax deposits on oil equipment surfaces. Mining of Mineral Deposits, 13(2), 34-40.

https://doi.org/10.33271/mining13.02.034

7. Chatterjee, S. \& Hadi, A. (2006). Regression analysis by example: Hoboken, NJ: Wiley.

8. Patsy, E. (2018). Advances In Unconventional Gas. Solutions to meet growing gas demand worldwide. A publication of Hart Energy Publishing. Retrieved from: www.hartenergy.com

9. Cambell, B.L. \& Chmilowski, W. (2005). Effective Stimultion of lowp ermeability gas in Western Canada. Journal Can. Petrol. Technol, 14(2). 17-22.

10. Mykhailovska, O., Rubel, V., Oleksiienko, O. \& Petruniak, M. (2018). Method of evaluation of stress - strain state rock around well. International Journal of Engineering \& Technology, 7(4.8). 312-318.

https://doi.org/10.14419/ijet.v7i4.8.27262

11. Ko, S.C.M., Stanton, P.M. \& Stephenson, D.J. (1985). Tertiary recovery potential of $\mathrm{CO} 2$ flooding in Joffre Viking Pool Alberta. Journal of Canadian Petroleum, 1. 36-43.

12. Heddle, G., Herzog, H. \& Klett, M. (2003). The economics of $\mathrm{CO}_{2}$ storage. Eds Massachusetts Institute of Technology, 111. 